\title{
Mechanisms for protecting the identity of small towns in Malaysia
}

\author{
Nur Farhana Azmi ${ }^{1, a}$, Faizah Ahmad ${ }^{1}$ and Azlan Shah Ali ${ }^{1}$ \\ ${ }^{1}$ Faculty of Built Environment, University of Malaya, Kuala Lumpur, Malaysia
}

\begin{abstract}
Built heritage constitute the very individuality of places hence to its identity. However, the built heritage in a small-scale town is nowadays subject to the triple threat of dilapidation, exhaustion and disappearance. Therefore, this paper attempts to examine the building regulations, guidelines and policies with regard to sustaining the unique features and identity of small towns through extensive review of literature. A semi structured interview was conducted amongst a purposive sample of nine stakeholders from different organizations involved in heritage matters in Malaysia; to investigate existing heritage protection measures impacting development of small towns. Using the qualitative software package NVivo 8.0, the study demonstrates that the towns are not only protected by legislative measures but also through community initiative activities and active collaboration between stakeholder groups. The paper concludes that a relatively strong policy and administrative framework are presently in place for protection and enhancement of built heritage despite some weaknesses in the existing mechanisms.
\end{abstract}

\section{Introduction}

Place identity is essential to serve good environment for the future hence the concept has become an increasingly topical issue in recent years. The concept also has received further attention under present day condition where the identity of place is rapidly weakening due to continuing threat from the twenty-first-century requirements associated with development and modernization $[28,38]$. This can be associated with the notion of placelessness [42] or non-place [4], a term which denotes places without meaning.

The term place identity has been widely discussed in various academic research reflecting the vitality of this concept. Lynch [32] conceptualized place identity as that which provides its individuality, oneness or distinction from other places and thus is intrinsic to its recognition as a separable identity. Built heritage presents in heritage places has been identified by numerous researchers as one of the most dominant characters that constitute place distinctiveness [12, 19, 27, 33, 43, 45]. It became evident as cultural heritage has been used to create the sense of identity in several Asian countries such as China, Korea, Laos, Myanmar and Thailand [31].

This contention make strong justification for supporting the conservation of built heritage as a possible means of instigating, preserving and promoting the identity of a place $[3,27,29,37,45]$. Therefore, this paper attempts to examine the existing legislations, guidelines and policies with regard to sustaining the unique features and identity of places particularly towns of a small scale. These towns deserve further research attention as they have been largely overlooked [23, 25]

\footnotetext{
$\overline{{ }^{a} \text { Corresponding author: farhanazmi } @ u m . e d u . m y ~}$
}

and are nowadays subject to the triple threat of dilapidation, exhaustion and disappearance [54].

This paper begins with an overview of relevant international charters and guidelines as well as approaches to built heritage protection in Malaysia. Theoretical findings is further strengthened through a semi structured interview with key stakeholders from different organizations involved in heritage matters in Malaysia.

\section{Background}

\subsection{International charters and guidelines}

Interest in the protection of cultural built heritage are informed by an ever increasing number of international charters, resolutions and declarations that date back to the late $19^{\text {th }}$ century and the early $20^{\text {th }}$ century. Among these are charters, resolutions and declarations of the United Nations Educational, Scientific and Cultural Organization (UNESCO), the International Council for Monuments and Sites (ICOMOS) and the Council of Europe. Despite predominantly reflect European tradition of philosophy and practice, these documents have influenced and presented the basis to the formation of the many later legislations in other countries around the world.

\subsubsection{UNESCO}

The international organization of UNESCO has been in the forefront in developing globally recognized conventions, recommendations and declarations for 
cultural heritage protection since the 1960s. The 1964 Venice Charter and the 1972 World Heritage Convention have appeared to be the most internationally recognized instruments developed by the UNESCO.

\section{The Venice Charter 1964}

The 1964 International Charter on the Conservation and Restoration of Monuments and Sites represented a revision of the 1931 Athens Charter. A noteworthy difference between the two charters is the former restricts the use of modern techniques whereas traditional practices are recommended. The Charter also emphasizes the importance of respecting the original fabric, precise documentation of any intervention, the significance contributions from all periods to the building's character, and the maintenance of historic buildings for a socially useful purpose. Furthermore, it states that the principles guiding the preservation of ancient buildings should be laid down on an international basis, with each country being responsible for applying the plan within the framework of its own culture and traditions.

The formation of the Charter marks a major step towards better conservation of traditional buildings and places. It continues to be cited as the baseline document for international conservation philosophy and practice today [1].

\section{World Heritage Convention}

The Convention concerning the Protection of the World Cultural and Natural Heritage is the principal reference for decisions regarding World Heritage. The Convention has proven to be the most widely accepted instrument of international co-operation in the protection of cultural and natural heritage of outstanding universal value (OUV). This was reflected in the increase number of the State Parties adhered to the Convention, reaching 191 countries by year 2014. The duty of ensuring the identification, protection, presentation and transmission of the heritage to future generations belongs to the state on whose territories it is located (Article 4). On signing the Convention, the state can benefit from international assistance, and having sites inscribed on the World Heritage List which in turn serves as a catalyst to raising awareness of the site and its outstanding values [53].

Places inscribed on the list are consider as having OUV together with the values perceived by the local community. Although the latter often disregarded in the justification of OUV [25], the role of local communities has been increasingly addressed by the Convention itself.

\section{The Asia-Pacific Heritage Awards 2000}

While recognizing the achievement of the private sector and public-private initiatives in conserving cultural heritage throughout Asia and the Pacific, the awards for cultural heritage conservation also act as a catalyst for local preservation activity. As argued by [9], good conservation practice needs to be grounded in an understanding of the locality of place and its values.

\subsubsection{ICOMOS}

Founded in 1965 , the ICOMOS is the only global nongovernmental organization dedicated to the conservation of the world's monuments and sites. The ICOMOS serves a forum for professional dialogue and a vehicle for the collection, evaluation and dissemination of information on conservation principles, techniques and policies. Therefore, it played a decisive role as world leader in the understanding and protection of cultural heritage [2]. Adopted the Venice Charter 1964 as its principal document, several of the ICOMOS national committees have independently developed charters on the principles of conservation within their own culture and traditions.

\section{Bruges Resolutions 1975}

The rationale for acknowledging the Resolutions on the Conservation of Smaller Historic Towns in this study inherently lies in its universal appliance to the conservation of smaller historic towns. There is no exact definition of town's boundary and in the context of small towns in South-East Asia, little is known about the characteristics of the towns [23]. By listing a number of its features, the dearth is however covered more or less in the Resolutions. The towns is characterized by problems in common or by specific features (size, cultural context, and economic function); its historic core which still marks the center of social life and business and contains a large proportion of residences; unspoilt surrounding landscape; balanced and diversified community structure; and its economic role.

Article 3 of the Resolutions set forth several common problems that have been plaguing the towns. Following these, the Resolutions advocate that any surviving links with the past should not be allowed to atrophy otherwise the national and cultural identity of the countries will be irremediable impoverished. Governments are encourages to provide planning authorities with the responsibility for protecting their historic towns against the pressure of excessive expansion and industrialization. Furthermore, regional policy must also take into account the needs of the towns and ensure their conservation by assigning them a role in keeping with their special structure; therefore plea for coordination at the planning stage of all public authority policies. Other measures propose by the resolutions comprise planning at the local level to retain and enhance the values of the towns; development of methods for surveying, assessing and protecting the towns' character; and stimulation of a sense of pride and responsibility among the local inhabitants.

\section{Tlaxcala Declaration 1982}

Acknowledging the importance of small settlements as key witnesses to our cultures, the Declaration on the Revitalization of Small Settlements emphasizes the local and national governments' responsibility in preserving the places. It also recognizes the rights of local communities to be involved in making decisions and work regarding the conservation of their towns. However, the Declaration stipulates that the procedures should be 
properly developed, and the works require efforts from multidisciplinary team and improvements on social service and infrastructure within a sensitive context while taking into local values and traditions.

\section{Washington Charter 1987}

The Charter for the Conservation of Historic Towns and Urban Areas 1987 concerns not only the large historic urban areas but also the smaller cities, towns and historic quarters. These areas embody values beyond their role as historical documents. The Charter advocates that conservation principles must embrace those steps necessary for the protection of such towns and areas as well as their development and harmonious adaptation to contemporary life. This should be preceded by multidisciplinary studies and documentation of the existing historic area. Furthermore, the Charter was found to be the first charter adopted by the ICOMOS that addresses the concept of public participation in conservation process [41]. In order to encourage their involvement, a general information programme should be set up for all residents beginning with children of school age.

\section{Principles for the Recording of Monuments, Groups of Buildings and Sites 1996}

The Principles perceives the documenting process as an effective tool to acquire an understanding of cultural heritage, its value and evolution; promote the interest and involvement of the people in the preservation; permit informed management and control of construction works and of all change to the cultural heritage; and to ensure that the maintenance and conservation of the heritage is sensitive to its physical form, materials, construction and its cultural significance.

The methods of recording should be appropriate and the complete report of any recording should be disseminated and made publicly available. The Principles states the complexity of the recording and interpretation processes requires the involvement of skilled individuals working in collaboration. As highlighted by [25], the conservation and management of historic areas and properties has increasingly become a shared field.

\section{The Burra Charter (1979, Revised 1981, 1988, 1999)}

Using the Venice Charter as a starting point, the Australian National Committee of ICOMOS decided that the Charter for Places of Cultural Significance to be written for Australian context. The Burra Charter is differentiated with the Venice Charter on the basis of its application to all places of cultural significance, not just the monuments covered by the older document. To Australian, the Charter is the most significant document on the basic principles and procedures for the conservation and management of heritage places [20]. This is evident as it has been widely adopted not only in Australia but also in other parts of the world. The strength of the Charter lies in its universal approach, clear methodology and its advocacy of conservation plan. Furthermore, the Charter provides detailed guidelines for establishment of cultural significance, development of conservation policy, and procedures for undertaking studies and reports.

\section{The Nara Document on Authenticity 1994}

The Document addresses the need for a broader understanding of cultural diversity and cultural heritage as it relates to the notion of authenticity of heritage. The document states that the understanding authenticity plays a fundamental role in all scientific studies of the cultural heritage, in conservation and restoration planning, as well as within the inscription procedures used for the World Heritage Convention and other cultural heritage inventories. For [50], the document marked a conceptual shift which allowed the inscription of wooden buildings in the World Heritage List.

The respect for other cultures, values, and the tangible and intangible expressions that form part of the heritage requires that heritage properties must be considered and judged within the cultural contexts to which they belong. Critical to this is the notion that authenticity is not a restrictive concept.

\subsubsection{The Council of Europe}

Since 1989, the Council has involved in heritage education and continues these activities in the framework of the European Heritage Days, a joint programme of the Council and the European Union which is held in September of each year. The Council's work in promoting architectural heritage has resulted in several standards, charters and conventions.

\section{The European Charter of the Architectural Heritage 1975}

The Charter is aimed at developing a common European policy for the protection of architectural heritage. Although emphasis is placed on the Europe's heritage, the Charter is significant in a way it refers architectural heritage to be embodied with cultural values [7]. More importantly, it contains the first mentions of the economic values, which is one of the major preoccupations in present-day literatures of the conservation discipline. Furthermore, the Charter acknowledges the introduction of modern architecture into historic areas provided that the existing context is fully respected and traditional materials are used [44]. While achieved through sensitive restoration techniques and appropriate functions, this integration is largely depends on legal, administrative, financial and technical support

\section{The Granada Convention}

The adoption of the Convention for the Protection of the Architectural Heritage of Europe 1985 was a consecration as it marked twenty years of European cooperation on architectural heritage and had included the 
principles of integrated conservation of the heritage. The Convention stipulates the need for cooperation at all levels, and for the public to participate and be informed. As the first step towards subsequent legal protection, the Convention emphasizes the need for any architectural heritage to be surveyed and inventoried (Article 2).

\subsection{Legislative approaches to built heritage conservation in Malaysia}

In Malaysia, the emergence of heritage building conservation practice can be traced back to the preindependence period, proven by the introduction of the Treasure Trove Ordinance 1951 which was later enacted as Treasure Trove Act 1957 (Act 542) [55]. The postindependence period particularly in March 1983 saw the first public outcry in an attempt to save the Loke Chow Kit's house [51]. For [17], the country's first successful conservation project involving adaptive reuse of the Kuala Lumpur Central Market around 1986 has been recognized as a pioneer for the development of building conservation activities in Malaysia. The practice has become more vigorously in recent times with the recognition of the Archaeological Heritage of Lenggong Valley in Perak as a UNESCO World Heritage Site in 2012.

An increasingly interest in building conservation activities also has led to the formulation of several acts, policies, plans and guidelines on protection of built heritage. These are discussed in the following sections according to the structure of the Malaysian federal, state and local governments. As highlighted by [39] and [55], heritage conservation in Malaysia is a shared legislative responsibility between the federal and state government.

\subsubsection{Federal Government}

The Ministry of Tourism and Culture Malaysia and the Ministry of Urban Wellbeing, Housing and Local Government are the two authorities responsible for protection and management of built heritage at the federal level in Malaysia.

The establishment of the Ministry of Tourism and Culture Malaysia in year 2004 paved way for the formulation of the National Heritage Act 2005. This reflects the government's growing commitment to preserving nation's cultural heritage [1]. The department that is responsible for enforcing the provisions placed under the Act is the Department of Heritage. The Department of Museums Malaysia is another department placed under the Ministry which holds the responsibilities to preserve Malaysian historical, cultural and natural heritage.

\section{National Heritage Act 2005 (Act 645)}

The National Heritage Act 2005 is a comprehensive Act that grants the conservation and preservation of National Heritage, natural heritage, tangible and intangible cultural heritage, underwater cultural heritage, treasure trove and other manifestations such as heritage food and heritage persons. The Act is enforced and administered by the Commissioner of Heritage appointed by the Ministry of Tourism and Culture Malaysia.

Based on UNESCO World Heritage Convention, the Act was legalized to replace the Treasure Trove Act 1957 and the Antiquities Act 1976. In contrast with the Antiquities Act 1976, this Act does not limit heritage to properties of hundred years and above. Vague criteria for listing of built heritage outlined in the former Antiquities Act have also been addressed by this new Act. Notwithstanding the fact, the Act is silent as to the criteria of listing an object having cultural heritage significance as compared to those being listed as National Heritage.

Section 23 of the Act provides for the establishment of a National Heritage Register as a national reference which can be inspected by the members of the public. This implies the importance of public participation in the field of heritage conservation. However, [39] argued that the Act is still vague as to the obligatory duty of the community to inform or propose to the Commissioner about heritage objects. Other deficiencies highlighted include absence on the criteria of archaeological impact assessment (AIA); conservation measures to the listed objects in the Register; lack of consideration of the issues of maintenance and management of the buildings; and limited power empowered to the National Heritage Department as conservation of buildings falls subtly under the jurisdiction of local authorities [22, 37, 39].

\section{Town and Country Planning Act 1976 (Act 172)}

Town and Country Planning Act 1976 is closely relate with the built heritage by means of development plans and development control. The Act was amended four times over the years from 1993 to 2007. The second amendment of the Act in year 1995 denotes direct incorporation of historic buildings into the Act. Specifically, where the development is in respect of a building with special architecture or historical interest, the applicant is to provide particulars to identify the building and measures for its protection and enhancement [Subsection 21B (1)(b)]. Likewise, the local planning authority shall also impose appropriate conditions when dealing with development that involves the erection of a new building, the re-erection or extension of a building [Subsection $22(5)(i)]$ or any addition or alteration to an existing building with special architecture or historical interest [Subsection $22(5)(\mathrm{j})]$.

\section{Local Government Act 1976 (Act 171)}

Local Government Act 1976 governs the powers of local authorities and shall only apply to Peninsular Malaysia. Subsection 101 (c)(iv) empowers the local authority to maintain or contribute to the maintenance of historical buildings or sites and acquire any land for the purpose of or in connection with the maintenance of historical buildings or sites [14]. Subsection 102 (f) further enables the local authority to provide for the establishment, regulation and management of any historical building or site. 


\section{Street, Drainage and Building Act 1974 (Act 133)}

The erection of buildings is also loosely bonded by the Street, Drainage and Building Act 1974 [6]. In regards to the preservation of buildings, the State Authority has the right to make by laws in the construction, paving, width and level of arcades and footways; the construction, alteration and demolition of buildings, and the methods and materials to be used; and the minimum timber or other material content in any building.

\subsubsection{State Government}

With the exception of the three federal territories which directly governed by the federal government, each state in Malaysia is headed by Chief Minister who is automatically the Chairman of State Planning Committee. The committee is the approving authority for development plans and may issue directives as well as policies which the local authority must comply. Development plans means the local plan or the structure plan for the area in which the land or building is situated [16].

\section{State Structure Plans}

The State Structure Plan is a statutory planning document which sets out the policies and general proposals for the development and other use of land within each state and thus providing guidance for spatial development. The plan also provides the framework for the preparation of a statutory local plan covering each district of the state. The structure plan has to confirm to the provisions of the national economic, social, physical, environmental and conservation policies. The plan is provided by State Director of Town and Country Planning, approved by the State Planning Committee and need to be agreed by the state authorities.

\subsubsection{Local Government}

Apart from responsibility for protection under the Local Government Act 1976, the Town and Country Planning Act 1972 empowers the local authority to control land use planning, control and conservation of all lands and buildings within their area. Accordingly, the local authority is required to prepare local plan for purposes of guiding planning development of its area or if any, special area plan for any part of its area.

\section{Local Plans}

A local plan is detailed map and written statement prepared to elaborate the policies set out in the structure plan. The plan by their consultative process of preparation acts as contractual agreements on the use of land within the planning areas between the local planning authorities, the local residents and land owners [34]. The plans also concerns with the protection and improvement of the physical environment and natural topography; and the preservation and enhancement of character and appearance of buildings in the area of local plan [16].

\section{Special Area Plan}

The Special Area Plan is a specific action plan for an area that has been identified by the state of local authority. The plan is prepared in the form of detailed local plans by the State Director or local authority pursuant to Section 16B of the Town and Country Planning Act 1976. It includes detailed information on the type of treatment, implementing agencies, phasing, costing and funding of a certain proposed project. The plan allows local authority to expedite an action plan for an area for the purpose of whether to immediately develop, redevelop, further improve, conserve or manage the area.

\subsubsection{Non-governmental Bodies}

The Heritage of Malaysia Trust and Penang Heritage Trust are the two non-governmental bodies concerned with the conservation of built heritage in Malaysia.

\section{Heritage of Malaysia Trust}

The Heritage of Malaysia Trust is a registered charity trust that aims to promote conservation of Malaysia's built heritage through awareness and public support, education and technical support. Since its inception, the Trust has undertaken various building conservation projects, research, education and outreach programmes. The Trust also has played a distinctive role in establishing financing for heritage conservation project [18]. The Trust also provided inputs for the amendments to the Town and County Planning Act 2003 and inputs to the National Heritage Act 2005.

\section{Penang Heritage Trust}

Founded in 1986, the Penang Heritage Trust is a charitable non-governmental organization aimed at promoting the conservation of Penang's cultural and built heritage as well as fostering cultural education about the history and heritage of Penang. Despite its emphasis on Penang, the Malaysian Institute of Architects and the Penang Municipal Council were encouraged by the Trust's formation and organized the first international conference on urban conservation and planning in June 1986 [24]. The Trust also has played an active role in lobbying for George Town's listing as a world heritage site in 2008.

\section{Methodology}

The approach used in this study involves critical review of existing plans, policies and legislation with regard to sustaining the unique features and identity of small towns in Malaysia. The study however starts by reviewing the conservation charters and guidelines at the international level. The rationale for this is to familiarize with the specialized terminology used in the legislation and 
principles of heritage conservation. Furthermore, current conservation principles used in Malaysia are deeply rooted in the ICOMOS Burra Charter and the Venice Charter. The literature review is mainly acquired from officials documents published by government and private agencies, journals, theses, and other mass media outputs. This study is also informed by the semi-structured interviews with nine participants from four different categories of stakeholders representing the federal, state, and local government, and the non-governmental organization. The interviews are audio recorded and transcribed by the researchers to maintain the confidentiality of the data and to ensure closeness of the researchers with the data [52]. The transcriptions are then analysed using the qualitative software package NVivo 8.0. The summary models imported from NVivo are created throughout the analysis process to visualize the connections between various dimensions of constructs, concepts and categories identified in the interviews.

\section{Findings and discussion}

Findings from the interviews in Table 1 demonstrated that there are two forms of protection mechanisms currently available in protecting built heritage in Malaysia particularly formal and informal mechanisms. [26] and [35] differentiate the two mechanisms by the formal prescribed through formal legal processes whereas the informal mechanisms or the so-called 'communitybased system' often derived from practices and belief systems carried out by local communities. As suggested by [46], the best approach for protecting and managing historic places can be achieved through a partnership between community members and appropriate heritage and conservation professionals. In line with the international, national, state and local approaches to built heritage conservation discussed in Section 2.0, the presence of a wide range of protection mechanisms as identified by the interviewees indicates that a relatively strong policy framework exists for protection of built heritage in Malaysia.

All interviewees mentioned the National Heritage Act 2005 as one of the important mechanisms available in protecting nation's built heritage. As argued by [39], the Act is the only specific statute on the preservation of cultural heritage that cover various matters on cultural heritage in Malaysia. According to two interviewees, the Act provides more holistic approach to the issue relating to the declaration of national heritage as all places including those that are of local significance possess equal opportunities and rights under the Act to be recognized as heritage or national heritage provided that the significance is proven. However, as highlighted in Section 2.2.1, the Act is silent to the criteria of listing an object as of having cultural heritage significance into the Heritage List compared to those being listed in the National Heritage List.
Table 1. Perceptions of heritage protection mechanisms in Malaysia

\begin{tabular}{|c|c|c|}
\hline Concepts & $\begin{array}{c}\text { Emergent } \\
\text { themes }\end{array}$ & Constructs \\
\hline \multirow{10}{*}{$\begin{array}{c}\text { Heritage } \\
\text { protection } \\
\text { mechanisms } \\
\text { available in } \\
\text { Malaysia }\end{array}$} & \multirow[t]{8}{*}{ Formal } & $\begin{array}{l}\text { Federal Territory (Planning) } \\
\text { Act } 1982 \text { (Act 267) }\end{array}$ \\
\hline & & $\begin{array}{l}\text { International charters and } \\
\text { guidelines }\end{array}$ \\
\hline & & $\begin{array}{l}\text { Local Government Act } 1976 \\
\text { (Act 171) }\end{array}$ \\
\hline & & Local planning schemes \\
\hline & & $\begin{array}{l}\text { National Heritage Act } 2005 \\
\text { (Act 645) }\end{array}$ \\
\hline & & $\begin{array}{l}\text { Street, Drainage and } \\
\text { Building Act } 1976 \text { (Act 172) }\end{array}$ \\
\hline & & $\begin{array}{l}\text { Town and Country Planning } \\
\text { Act } 1976 \text { (Act 172) }\end{array}$ \\
\hline & & $\begin{array}{l}\text { Uniform Building By-law } \\
\text { Act } 1984\end{array}$ \\
\hline & \multirow[t]{2}{*}{ Informal } & $\begin{array}{l}\text { Collaboration between } \\
\text { different stakeholders }\end{array}$ \\
\hline & & $\begin{array}{l}\text { General community } \\
\text { initiatives }\end{array}$ \\
\hline
\end{tabular}

Findings from the interviews $(n=5)$ reveal that the National Heritage Act 2005 also emphasizes on matters under the Town and Country Planning Act 1976 particularly with regard to the preparation of development plans, application for planning permission, preparation of conservation management plan and implementation of provisions on areas gazette as heritage sites. As discussed in Section 2.2.1, the Act itself is closely relate with the built heritage by means of development plans and development control. This corresponds with the suggestion recommended by international charters and conventions such as the World Heritage Convention, the Washington Charter, the European Charter and the Granada Convention on the need to integrate conservation of built heritage into the land use planning processes. While the Act does not govern the three federal territories of Malaysia, one interviewee acknowledges the Federal Territory (Planning) Act 1982 as the planning and enforcement document for Malaysia's Federal Territory.

Furthermore, all interviewees agreed that the local authority conservation guidelines served an important tool in the protection of built heritage at the local level. Nevertheless, two interviewees argued that most of the guidelines used nowadays are likely to be similar to one another as they were issued by the same consultant. As a matter of fact, different places should be governed by different set of guidelines because they are coming from completely different aspects of what makes the places, origins and people. As argued by [40], there can be no general checklist that is applicable to all sites. The findings further demonstrate that the guidelines also often viewed only as recommendations and consequently many illegal works on historic properties were reported. This demonstrates the insufficiency of the mechanism and the need for specific heritage legislation. This is reasonable 
owing to a direct mode of operation and the certainty of regulatory instrument's effect [48].

Two interviewees said that built heritage was also protected through the Local Government Act 1976 as the Act has provided allocations and conferred power to local authorities to take the necessary measures for the preservation of historic buildings. The Street, Drainage and Building Act 1974 and Uniform Building By-law Act 1984 were mentioned as other protection mechanisms by interviewees from the state and local government respectively.

Interestingly, the interviews results $(n=2)$ suggest that local community initiative programs and active collaboration between stakeholder groups had provided some degree of protection for built heritage as they highlight something about particular places. Examples of these are the exhibitions or huge public outcry that brings about public awareness. As discussed in Section 2.2, one of the earliest pioneers of building conservation movement in Malaysia also has led by a group of concerned community members. The fact that the local community plays a vital role in the heritage field is also reflected in other world regions such as in London, Australia, England and Caribbean Island [11, 10, 40, 30]. For [36], this is especially important when the objects are not of major national interest, not listed and not preserved by heritage authorities.

\section{Conclusion}

To be successful and competitive in an increasingly globalized world, cities and towns need to be more distinctive, unique and special for which it can be recognized as a separable entity. The desire and commitment to plurality and differentiation against standardization and monotonous image of a place led to greater appreciation of built heritage which increasingly touted as one of the fundamental components that have a significant influence on the identity of place. Not only in major urban centers, built heritage also makes a continuing contribution to the image and identity of small cities alike. Given the importance of cultural built heritage in conferring local distinctiveness, measures need to be taken to ensure the continuity and protection of these physical structures especially under present day condition where the identity of place is rapidly weakening. By bringing together nation's approaches as well as relevant international charters and guidelines for built heritage protection, this paper can be regarded as the first of many fruitful contributions that examine heritage protection mechanisms at the local level. Particularly, the study revealed that built heritage is not only protected by legislative measures alone but also through community initiative activities and practices. Therefore, it is crucial that future legislative framework recognizes the rights and role of local communities in the protection of their towns.

\section{Acknowledgement}

The authors gratefully acknowledge the financial support of the Postgraduate Research Grant (PPP), grant no PG003-2012B established at the University of Malaya, Institute of Research Management and Consultancy (IPPP).

\section{References}

1. A.H. Ahmad Sarji, Town Planning and Conservation: What needs to be done? (2005)

2. G.F. Araoz, J. Cult. Herit. Manage. Sustain. Dev. 1, 1, 55-60 (2011)

3. Arazi, K. Faris, M. Sodangi, Mod. Appl. Sci. 4, 11, 66-77 (2010)

4. M. Arefi, J. Urban Des. 4, 2, 179-193 (1999)

5. Australia ICOMOS, The Australia ICOMOS charter for places of cultural significance: The Burra Charter 1999 (Australia ICOMOS, Sydney, 2000)

6. M. Badaruddin, Paper presented Paper presented at the Korea, China, Japan, Phillipines, Spain, Turkey, India and USA Joint World Cultural Tourism Conference 2005 (2005)

7. Council of Europe, The European Charter of Architectural Heritage (1975)

8. Council of Europe, The Granada Convention (Convention for the protection of the architectural heritage of Europe) (1985)

9. R.A. Engelhardt, J. Pres. Technol. 41, 2-3, 57-65 (2010)

10. F. Ahmad, Protecting the built heritage of capital cities: Case studies of Perth and Kuala Lumpur (Curtin University of Technology, Perth, 2009)

11. J.M. Gard'ner, Int. J. Herit. Stud. 10, 1, 75-92 (2004)

12. P. Goad, L.T. Ngiom, Recent Malaysian architecture (Pesaro Publishing, Singapore 2007)

13. Government of Malaysia, Antiquities Act (Act170) (National Printing Document 1976)

14. Government of Malaysia, Local Government Act (Act171) (National Printing Document 1976)

15. Government of Malaysia, National Heritage Act (Act645) (National Printing Document 1976)

16. Government of Malaysia, Town and Country Planning Act (Act172) (National Printing Document 1976)

17. S.N. Harun, P. Eng. 20, 41-53 (2011)

18. Heritage of Malaysia Trust, Town planning and conservation: What needs to be done? Retrieved 18 April, 2012 from http://www.badanwarisan.org.my/content/?cid=219 (2008)

19. Heritage of Malaysia Trust, Comprehensive assessment needed for KL's Chinatown Retrieved 30 April, 2012 from http://www.badanwarisan.org.my/content/?cid=381 (2011)

20. Heritage Perth, The Burra Charter Retrieved 21 October, 2012 from http://heritageperth.com.au/yourheritage/the-burra-charter/ (2012) 
21. ICOMOS, Resolutions on the conservation of smaller historic towns (The Bruges Resolution) (1975)

22. A. Idrus, F. Khamidi, M. Sodangi, Mod. Appl. Sci. 4, $11,66-70(2010)$

23. J.C. Jackson, T. Ins. Brit. Geogr. 61, 65-80 (1974)

24. G. Jenkins, Contested space: Cultural heritage and identity reconstructions. Conservation strategies within a developing Asian city (Lit Verlag, Zurich, 2009)

25. J. Jokilehto, ICCROM and the conservation of cultural heritage: A history of the organization's first 50 years, 1959-2009 (2011)

26. A. Jopela, Conserv. Manag. Archaeol. Sites (2011)

27. K. Kamarul Syahril, A.W. Lilawati, A. Ghafar, Paper presented at the $2^{\text {nd }}$ International Conference on Built Environment in Developing Countries 2008 (University Science Malaysia, 2008)

28. M.H. Khairul Amin, U. Norsidah, Soc. Behav. Sci. 153, 689-699 (2014)

29. Q.Y. Lee, Y.M. Lim, Int. J. Human Soc. Sci. 5, 3, 140-145 (2010)

30. M.J. LeFebvre, J. Island Coastal 8, 2, 311-314 (2013)

31. W.S. Logan, The disappearing "Asian" city: Protecting Asia's urban heritage in a globalizing world (First ed.) (Oxford University Press, United States, 2002)

32. K. Lynch, The image of the city (Joint Center for Urban Studies, United States, 1960)

33. J.R. Mansfield, Eng. Constr. Arch. Manag. 15, 3, 270-281 (2008)

34. Ministry of Housing and Local Government, National Physical Plan 2 (2010)

35. A. Mumma, Legal frameworks for the protection of immovable cultural heritage in Africa (ICCROM, Rome, 2005)

36. L. Mydland, W. Grahn, Int. J. Herit. Stud. 18, 6, 564587 (2012)

37. W.A.Z. Noor Amila, A. Alias, I. Arazi, Paper presented at the International Conference on Sustainable Building and Infrastructure (2010)

38. U. Norsidah, Asian. J. Env. Behav. Stud. 61-76 (2010)

39. M. Nurulhuda Adabiah, A. Nuraisyah Chua, Paper presented at the International Conference on Tourism Development Penang (Malaysia 2013)

40. J. Pendlebury, Town Plann. Rev. 70, 4, 479-500 (1999)

41. M. Rasouli, L. Khirfan, Paper presented at the Canadian Association of Geographers' Annual Meeting (Waterloo, Ontario, 2012)

42. E. Relph, Place and placelessness (Pion Limited, Brondesbury Park, London, 1976)

43. M. Ripp, U. Eidenschink, C. Milz, Facilities 29, 7-8, 286-302 (2011)

44. D. Rodwell, Conservation and sustainability in historic cities (Blackwell Publishing, Oxford, UK, 2007)

45. S. Shuhana, Townscape revisited: Unravelling the character of the historic townscape in Malaysia
(Universiti Teknologi Malaysia, Johor Bahru, Malaysia, 2011)

46. B. Smith, Proceedings of the Conservation Theme of the $5^{\text {th }}$ World Archaeological Congress Washington D.C., 22-26 June 2003 (The Getty Conservation Institute, Los Angeles, 2006)

47. N. Tavakoli, Paper presented at the 14th International Planning History Society Conference (2010)

48. D. Throsby, Seven questions in the economics of cultural heritage (pp.13-30). In M. Hutter, Economic perspectives of built heritage (McMillan Press, London, 1997)

49. UNESCO World Heritage Centre, Basic texts of the 1972 World Heritage Convention (UNESCO, Paris, France, 2005)

50. S.V. Uytsel, P. Jurcys, J. Jpn. 34, 309-316 (2013)

51. W.I. Wan Hashimah, Asian. J. Env. Behav. Stud. 1, 3, 73-82 (2010)

52. S. Watts, Qual. Res. Psychol. 11, 1-14 (2014)

53. World Heritage Convention, World Heritage List UNESCO Retrieved 2 July, 2012 from http://whc.unesco.org/en/list/ (2012)

54. D. Yuksel, D. Iclal, Paper presented at the $15^{\text {th }}$ ICOMOS General Assembly and International Symposium: Monuments and sites in their setting conserving cultural heritage in changing townscapes and landscapes (Xi'an, China, 2005)

55. M.Y. Yuszaidy, D. Hanapi, K. Ab Samad, Jurnal Melayu 8, 173-188 (2011) 